\title{
Contribution of serotonin receptor subtypes to hallucinogenic activity of 25I-NBOMe and to its effect on neurotransmission
}

\author{
Monika Herian ${ }^{1} \cdot$ Adam Wojtas $^{1}$ - Małgorzata Katarzyna Sobocińska ${ }^{1} \cdot$ Mateusz Skawski ${ }^{1}$. \\ Alejandro González-Marín ${ }^{1} \cdot$ Krystyna Gołembiowska $^{1}$ (이
}

Received: 31 July 2020 / Revised: 19 October 2020 / Accepted: 22 October 2020 / Published online: 10 November 2020

(c) The Author(s) 2020

\begin{abstract}
Background 4-Iodo-2,5-dimethoxy- $N$-(2-methoxybenzyl)phenethylamine (25I-NBOMe) is a potent serotonin (5-HT) receptor agonist with hallucinogenic properties. The aim of our research was to examine the role of the 5- $\mathrm{HT}_{2 \mathrm{~A}}, 5-\mathrm{HT}_{2 \mathrm{C}}$ and $5-\mathrm{HT}_{1 \mathrm{~A}}$ serotonin receptor subtypes in 25I-NBOMe hallucinogenic activity and its effect on dopamine (DA), 5-HT and glutamate release in the rat frontal cortex.

Methods Hallucinogenic activity was investigated using the wet dog shake (WDS) test. The release of DA, 5-HT and glutamate in the rat frontal cortex was studied using a microdialysis in freely moving rats. Neurotransmitter levels were analyzed by HPLC with electrochemical detection. The selective antagonists of the 5- $\mathrm{HT}_{2 \mathrm{~A}}, 5-\mathrm{HT}_{2 \mathrm{C}}$ and $5-\mathrm{HT}_{1 \mathrm{~A}}$ serotonin receptor subtypes: M100907, SB242084 and WAY100635, respectively were applied through a microdialysis probe.

Results The WDS response to 25I-NBOMe (1 and $3 \mathrm{mg} / \mathrm{kg}$ ) was significantly reduced by local administration of M100907 and SB242084 (100 nM). The 25I-NBOMe-induced increase in glutamate, DA and 5-HT release was inhibited by M100907 and SB242084. WAY100635 had no effect on 25I-NBOMe-induced WDS and glutamate release, while it decreased DA and 5-HT release from cortical neuronal terminals.

Conclusion The obtained results suggest that $5-\mathrm{HT}_{2 \mathrm{~A}}$ and $5-\mathrm{HT}_{2 \mathrm{C}}$ receptors play a role in $25 \mathrm{I}-\mathrm{NBOMe}$-induced hallucinogenic activity and in glutamate, DA and 5-HT release in the rat frontal cortex as their respective antagonists attenuated the effect of this hallucinogen. The disinhibition of GABA cells by the $5-\mathrm{HT}_{1 \mathrm{~A}}$ receptor antagonist seems to underlie the mechanism of decreased DA and 5-HT release from neuronal terminals in the frontal cortex.
\end{abstract}

Keywords $25 \mathrm{I}-\mathrm{NBOMe} \cdot$ Hallucinogenic activity $\cdot$ Neurotransmission $\cdot 5-\mathrm{HT}_{2 \mathrm{~A} / 2 \mathrm{C} / 1 \mathrm{~A}}$ receptor antagonists

\section{Introduction}

4-Iodo-2,5-dimethoxy- $N$-(2-methoxybenzyl)phenethylamine (25I-NBOMe) is a synthetic $N$-methoxybenzyl derivative of 2C-I (4-iodo-2,5-dimethoxyphenethylamine), a compound from the phenylalkylamine family and a potent 5-HT receptor agonist. 25I-NBOMe exhibits high in vitro binding

Electronic supplementary material The online version of this article (https://doi.org/10.1007/s43440-020-00181-4) contains supplementary material, which is available to authorized users.

Krystyna Gołembiowska

nfgolemb@cyf-kr.edu.pl

1 Department of Pharmacology, Maj Institute of Pharmacology, Polish Academy of Sciences, 12 Smętna, 31-343 Kraków, Poland affinities for 5- $\mathrm{HT}_{2 \mathrm{~A}}, 5-\mathrm{HT}_{2 \mathrm{C}}$ and $5-\mathrm{HT}_{1 \mathrm{~A}}$ receptors $(K i=0.6$, 4.6 and $1800 \mathrm{nM}$, respectively) [1].

Serotonin receptors are the main target for the action of classical hallucinogens. Serotonergic hallucinogens that act via these receptors include indoleamines and phenylalkylamines which display a high binding affinity for serotonin 5- $\mathrm{HT}_{2 \mathrm{~A}}, 5-\mathrm{HT}_{2 \mathrm{C}}$ and $5-\mathrm{HT}_{1 \mathrm{~A}}$ receptor subtypes [2]. Serotonin-2A receptors are expressed mainly on the apical dendrites of pyramidal cells in layer $\mathrm{V}$ of the cerebral cortex [3] with a minor localization to GABAergic interneurons [4, 5]. Their activation leads to enhancement of cortical glutamate release, which is a common mechanism of action of hallucinogens [6-9]. Serotonin-2C receptors expressed on GABAergic cells in the deep layers of the prefrontal cortex may exert an inhibitory tone on pyramidal neurons by GABA release $[10,11]$, whereas $5-\mathrm{HT}_{1 \mathrm{~A}}$ as postsynaptic 
heteroreceptors are localized mainly on pyramidal neurons and on GABAergic interneurons [12].

Many hallucinogenic drugs that act as $5-\mathrm{HT}_{2 \mathrm{~A}}$ receptor agonists evoke a rhythmic paroxysmal rotational head movement in rodents, known in mice as head twitch response (HTR) and also referred to as a wet dog shakes (WDS) in rats [13]. It was shown that $5-\mathrm{HT}_{1 \mathrm{~A}}$ and $5-\mathrm{HT}_{2 \mathrm{C}}$ receptor activation negatively modulated the $5-\mathrm{HT}_{2 \mathrm{~A}}$-mediated effect on head twitch episodes in rodents [14]. It was proven that higher doses of some hallucinogenic agents, apart from the activation of 5- $\mathrm{HT}_{2 \mathrm{~A}}$ receptors, might also cause activation of $5-\mathrm{HT}_{2 \mathrm{C}}$ receptors which opposed the effect of $5-\mathrm{HT}_{2 \mathrm{~A}}$ receptor stimulation [15]. For instance, 2,5-dimethoxy4-iodoamphetamine (DOI)-elicited head twitch behavior was inhibited by competing $5-\mathrm{HT}_{2 \mathrm{C}}$ agonist activity [16]. However, there is evidence that stimulation of both $5-\mathrm{HT}_{2 \mathrm{~A}}$ and $5-\mathrm{HT}_{2 \mathrm{C}}$ receptors may be required for hallucinogenic activity [2]. Furthermore, 5- $\mathrm{HT}_{1 \mathrm{~A}}$ receptors co-expressing with $5-\mathrm{HT}_{2 \mathrm{~A}}$ receptors in cortical pyramidal neurons often show the opposite effect on common signaling pathways [17], which results in the inhibition of the functional effects mediated by $5-\mathrm{HT}_{2 \mathrm{~A}}$ receptors and attenuation of HTR episodes evoked by tryptamine-like hallucinogens [14].

There are studies confirming that 25I-NBOMe, through its agonist activity at the $5-\mathrm{HT}_{2 \mathrm{~A}}$ receptor, produces dosedependent increases in HTR/WDS episodes as well as back muscle contractions (BMC) in rodents $[6,13,18,19]$. Pretreatment with the selective 5- $\mathrm{HT}_{2 \mathrm{~A}}$ antagonist M100907 caused a significant reduction in WDS and BMC in rats, evoked by 25I-NBOMe [18]. Similarly, HTR elicited by 25I-NBOMe in mice was also blocked by M100907 [19]. Moreover, the increase in glutamate level induced by intracortical injections of DOI was blocked by M100907 [9]. $25 \mathrm{CN}-\mathrm{NBOH}$, another representative of the phenethylamine series of hallucinogens, evoked HTR episodes that were blocked by pretreatment with the $5-\mathrm{HT}_{2 \mathrm{~A}}$ antagonist ketanserin [20]. Instead, the 5- $\mathrm{HT}_{2 \mathrm{C}}$ receptor antagonist SB242084 produced a slight increase in the number of head twitches elicited by $25 \mathrm{CN}-\mathrm{NBOH}$ [20]. On the other hand, there is a study indicating that DOI-induced HTR episodes were reduced but not eliminated after pretreatment of mice with 5-HT $2 \mathrm{C}$ receptor antagonists (SB206553 or SB242084) [21].

Our previous study demonstrated that 25I-NBOMe exerted a potent effect on cortical glutamate, DA and 5-HT levels and induced hallucinogenic activity [6]. There are no data on the contribution of cortical 5-HT receptor blockade to the effect of 25I-NBOMe on brain neurotransmission correlated with behavioral response. Therefore, the aim of this study was to assess the role of serotonin $5-\mathrm{HT}_{2 \mathrm{~A}}, 5-\mathrm{HT}_{2 \mathrm{C}}$ and $5-\mathrm{HT}_{1 \mathrm{~A}}$ receptors in the changes induced by $25 \mathrm{I}-\mathrm{NBOMe}$ using selective 5-HT receptor antagonists (M100907, SB242084 and WAY100635). We examined the impact of
5-HT receptor antagonists, administered locally into the rat frontal cortex, on the changes in extracellular cortical levels of glutamate, DA and 5-HT induced by 25I-NBOMe. Shaking behavior was also tested as an indicator of hallucinogenic activity.

\section{Materials and methods}

\section{Animals}

All experiments were performed on male Wistar-Han rats (Charles River, Sulzfeld, Germany) weighting 280-320 g. The animals were initially acclimatized and housed in groups of 5 each in temperature $\left(23 \pm 1{ }^{\circ} \mathrm{C}\right)$ and humidity $(55 \pm 10 \%)$ controlled rooms under a $12 \mathrm{~h}$ light/dark cycle (light was turned on at 6 a.m.), with free access to tap water and standard laboratory food (VRF 1, Special Diets Services, Witham, UK). The experiments were conducted in accordance with the European regulations for animal experimentation (EU Directive 2010/63/EU on the protection of animals used for scientific purposes). The experimental protocols were approved by the Local Ethics Commission for Experimentation on Animals (Permit number: 187/2017). This article does not contain any studies with human participants by any of the authors.

\section{Drugs and reagents}

4-Iodo-2,5-dimethoxy- $N$-(2-methoxybenzyl)phenethylamine hydrochloride (25I-NBOMe) was purchased from Chiron AS (Trondheim, Norway). All chemicals used for high-performance liquid chromatography (HPLC) were obtained from Merck (Warszawa, Poland), O-phthalaldehyde (OPA) was from Sigma-Aldrich. Ketamine hydrochloride and xylazine hydrochloride were from Biowet (Pulawy, Poland). M100907, SB242084 dihydrochloride hydrate and WAY100635 maleate salt were from Sigma-Aldrich (Poznan, Poland).

\section{Drug administration}

Solutions of the antagonists were prepared by dissolving M100907, SB242084 and WAY100635 in artificial cerebrospinal fluid and were administered locally via reverse microdialysis. The value of $100 \mathrm{nM}$ was derived from the concentration-response curve of $5-\mathrm{HT}_{2 \mathrm{~A} / 2 \mathrm{C} / 1 \mathrm{~A}}$ receptor antagonists determined in preliminary experiments. The animals received single subcutaneous (sc) injections of 25I-NBOMe dissolved in $0.9 \% \mathrm{NaCl}$ at a dose of 1 or $3 \mathrm{mg} /$ $\mathrm{kg}$. These doses were established according to our previous study [6]. The control group was treated with antagonists 
and $0.9 \% \mathrm{NaCl}$ solution in the same way. The drug administration schedule is shown on the graph in Scheme 1.

\section{Brain microdialysis}

Animals were anesthetized intramuscularly with ketamine $(75 \mathrm{mg} / \mathrm{kg})$ and xylazine $(10 \mathrm{mg} / \mathrm{kg})$, placed in a stereotaxic apparatus (David Kopf Instruments, Tujunga, USA) and guide cannulas were implanted in the rat frontal cortex. The animals were allowed to recover for 3 days and then microdialysis probes (MAB 4.15.4.Cu AgnTho's AB, Lindingö, Sweden) were inserted according to coordinates $(\mathrm{mm})$ $\mathrm{AP}+2.7, \mathrm{~L}+0.8, \mathrm{~V}-6.5$ from the dura [22] and probe inlets were connected to a syringe pump (BAS, West Lafayette, IN, USA). The artificial cerebrospinal fluid (aCSF) composed of $\mathrm{NaCl}(147 \mathrm{mM}), \mathrm{KCl}(4 \mathrm{mM}), \mathrm{CaCl}_{2}(2.2 \mathrm{mM})$ and $\mathrm{MgCl}_{2}(1.0 \mathrm{mM})$ was delivered at a flow rate of $2 \mu \mathrm{L} /$ $\min$ for $2 \mathrm{~h}$ of washout period. After collection of four 20-min basal dialysate samples, appropriate 5-HT receptor subtype antagonists were administered through microdialysis probes. Following $1 \mathrm{~h}$ of drug infusion, rats were injected with appropriate 25I-NBOMe doses and sample collection continued for $240 \mathrm{~min}$. At the end of the experiment, the animals were sacrificed and their brains were examined histologically to ensure that probes were placed correctly (Fig. 1S, Supplementary data).

\section{Analytical procedure}

DA and 5-HT levels in dialysate fractions were analyzed by HPLC with amperometric detection using an Ultimate 3000 System (Dionex, Sunnyvale, CA, USA), electrochemical detector Coulochem III (model 5300; ESA, Chelmsford, MA, USA) with a 5020 guard cell, 5040 amperometric cell using a Hypersil Gold C18 column $(3 \mu \mathrm{m}, 100 \times 3 \mathrm{~mm}$; Thermo Fisher Scientific, Waltham, MA, USA) controlled by Chromeleon v.6.80 (Dionex, Sunnyvale, CA, USA) software. The mobile phase consisted of $0.1 \mathrm{M}$ potassium phosphate buffer adjusted to $\mathrm{pH} 3.8,0.5 \mathrm{mM} \mathrm{Na}{ }_{2}$ EDTA, $100 \mathrm{mg} / \mathrm{L}$ 1-octanesulfonic acid sodium salt, and 2\% methanol. The flow rate was $0.6 \mathrm{~mL} / \mathrm{min}$. The applied potential of a guard cell was $600 \mathrm{mV}$ and amperometric cell was $300 \mathrm{mV}$ with a sensitivity set at $10 \mathrm{nA} / \mathrm{V}$. The limit of detection of $\mathrm{DA}$ and 5 -HT in dialysates was $0.002 \mathrm{pg} / 10 \mu \mathrm{L}$ for DA and $0.01 \mathrm{pg} / 10 \mu \mathrm{L}$ for $5-\mathrm{HT}$.

Glutamate concentration in the extracellular fluid was measured electrochemically after derivatization with OPA/ sulfite reagent to form an isoindole-sulfonate derivative [23] using an Ultimate 3000 pump (Dionex, Sunnyvale, CA, USA), LC-4B amperometric detector with a cross-flow detector cell (BAS) and HR- 80 column $(3 \mu \mathrm{m}, 80 \times 4.6 \mathrm{~mm}$; ESA Inc, Chelmsford, MA, USA) controlled by Chromax 2005 (Pol-Lab, Warszawa, Poland) software. The mobile phase was composed of $100 \mathrm{mM}$ monosodium orthophosphate at $\mathrm{pH} 4.6$ and $4 \%$ methanol. The flow rate during analysis was set to $1 \mathrm{~mL} / \mathrm{min}$ and the applied potential of a 3-mm glassy carbon electrode was set at $+600 \mathrm{mV}$ at a sensitivity of $5 \mathrm{nA} / \mathrm{V}$. Glutamate-derivative peak was compared with the respective standard and the data were processed using Chromax 2005 (Pol-Lab, Poland) software. The limit of detection of glutamate in dialysates was $0.03 \mathrm{ng} / 10 \mu \mathrm{L}$.

\section{Wet dog shake test}

The wet dog shake (WDS) test was carried out after administration of drugs according to the procedure described by Nagayama and Lu [24] adapted to the experimental design. Shaking behavior was defined as a rapid, side-to-side rotational movement of the head with propagation to neck, shoulders and trunk, and each such episode was counted. Directly after administration of drugs, rats were observed by two independent and experienced experimenters who were blind to the treatments. The number of shakes was counted and totaled from 12 observation periods. Results were expressed as an average of sum values from 12 observation periods.

\section{Data analysis}

Drug effects on DA, 5-HT and glutamate release in the rat frontal cortex were analyzed with two-way repeated measures ANOVA on normalized responses followed by Tukey's

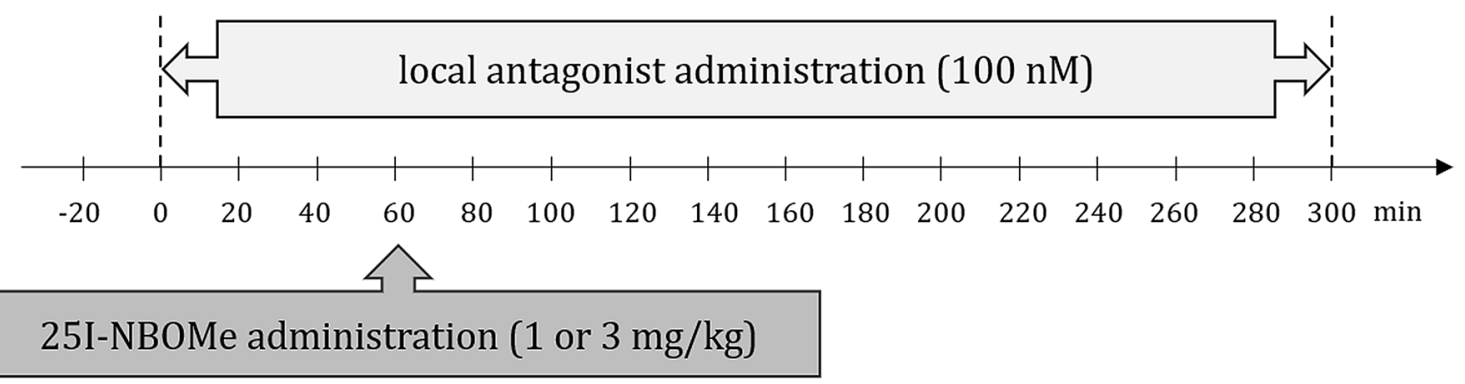

Scheme 1 The drug administration schedule is shown on the graph above 
post hoc test. All obtained data were presented as a percent of the basal level assumed to be $100 \%$. The total effects expressed as an area under the curve (AUC) representing the time-course of drug effects were analyzed with two-way ANOVA. The results from the WDS test were analyzed using two-way ANOVA followed by Tukey's post hoc test. The differences were considered significant if $p<0.05$. All statistical analyses were carried out using STATISTICA v.10 StatSoft Inc. 1984-2011 (San Francisco, CA, USA).

\section{Results}

\section{The effect of M100907, SB242084 and WAY100635 on 25I-NBOMe-induced increase in glutamate levels in the rat frontal cortex}

The extracellular levels of glutamate were not affected by administration through a dialysis probe, of the $5-\mathrm{HT}_{2 \mathrm{~A}}$ receptor antagonist $\mathrm{M} 100907,5-\mathrm{HT}_{2 \mathrm{C}}$ receptor antagonist
SB242084 and 5- $\mathrm{HT}_{1 \mathrm{~A}}$ receptor antagonist WAY100635 at a concentration of $100 \mathrm{nM}$ (Fig. 1a, c, e). 25I-NBOMe significantly increased extracellular glutamate levels $(p<0.01)$ in the frontal cortex. The dose of $1 \mathrm{mg} / \mathrm{kg}$ was more potent than the dose of $3 \mathrm{mg} / \mathrm{kg}$ (Fig. 1a, c, e). M100907 and SB242084 reduced the 25I-NBOMe-induced increase in the extracellular glutamate level in the frontal cortex to the level of control group (Fig. 1a, c). The 25I-NBOMe-induced increase in the extracellular glutamate level was not changed by WAY100635 (Fig. 1e). Two-way repeated measures ANOVA showed a significant effect of treatment with 25I-NBOMe and M100907 $\left(F_{3,18}=1987, p<0.0001\right)$, sampling period $\left(F_{11,198}=55\right.$, $p<0.0001)$, and time $\times$ treatment interaction $\left(F_{33,198}=29\right.$, $p<0.0001)$. There was also an effect of treatment with 25I-NBOMe and SB242084 $\left(F_{3,18}=133, p<0.0001\right)$ and time $\left(F_{11,198}=5.9, p<0.0001\right)$, and time $\times$ treatment interaction $\left(F_{33,198}=5.9, p<0.0001\right)$. The effect of treatment with 25I-NBOMe and WAY100635 was significant $\left(F_{3,18}=160\right.$, $p<0.0001)$, there was also an effect of time $\left(F_{11,198}=15\right.$,
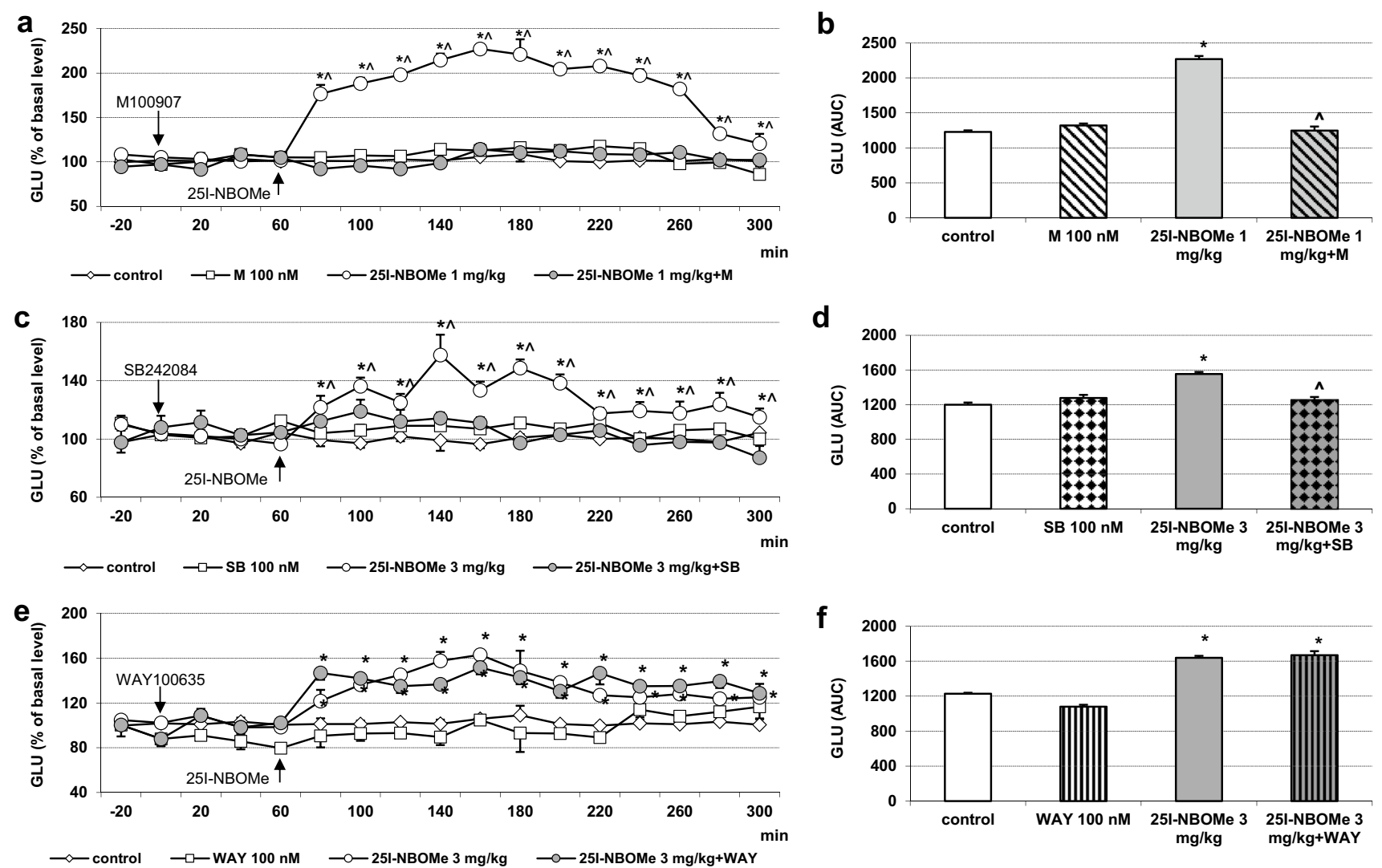

Fig. 1 The time-course (a, c, e) and total (b, d, f) effect of 25I-NBOMe and M100907, SB242084 and WAY100635, respectively on extracellular levels of glutamate (GLU) in the rat frontal cortex. The total effect was calculated as an area under the concentration-time curve (AUC) and expressed as the percent of control. Values are the mean \pm standard error of the mean (SEM), $n=5-6$ per experimental group. The administration of drugs is indicated with arrows. ${ }^{*} p<0.01$ vs. control group; ${ }^{\wedge} p<0.01 \quad 25 \mathrm{I}-\mathrm{NBOMe}$ vs. 25I-NBOMe + M100907, 25I-NBOMe + SB242084 or 25I-NBOMe + WAY100635 groups (two-way repeated measures ANOVA or two-way ANOVA where appropriate and Tukey's post hoc test) 
$p<0.0001)$ and time $\times$ treatment interaction $\left(F_{33,198}=6.1\right.$, $p<0.0001)$. The total effects expressed as AUC shown in Fig. 1b, d, f reflect the responses to 25I-NBOMe and 25I-NBOMe plus antagonists of $5-\mathrm{HT}_{2 \mathrm{~A} / 2 \mathrm{C} / 1 \mathrm{~A}}$ receptors with respect to cortical glutamate release presented as time-course curves. Data set of the total effects was subjected to two-way ANOVA. The group factor was significant for 25I-NBOMe in each case: $F_{1,18}=1867, p<0.0001$ (Fig. 1b); $F_{1,18}=127, p<0.0001$ (Fig. 1d) and $F_{1,18}=470$, $p<0.0001$ (Fig. 1f). The group factor was also significant for M100907 and SB242084: $F_{1,18}=1708, p<0.0001$; $F_{1,18}=91, p<0.0001$ (Fig. $1 \mathrm{~b}$ and $1 \mathrm{~d}$, respectively), but not for WAY100635: $F_{1,18}=3.43, p<0.08$ (Fig. 1f). The group factor was significant for 25I-NBOMe + M100907 and 25I-NBOMe +SB242084: $F_{1,18}=1998, p<0.0001$; $F_{1,18}=154, p<0.0001$, respectively (Fig. $1 \mathrm{~b}$ and $1 \mathrm{~d}$ ), but not for 25I-NBOMe + WAY100635: $F_{1,18}=0.08, p<0.79$ (Fig. 1f). Post hoc Tukey's test showed a significant difference between control and 25I-NBOMe (1 and $3 \mathrm{mg} /$ $\mathrm{kg})$ and 25I-NBOMe + WAY100635 groups $(p<0.01)$
(Fig. 1b, d, f) and between 25I-NBOMe + M100907 and 25I-NBOMe + SB242084 in comparison to 25I-NBOMe alone $(p<0.01)$ (Fig. 1b and d).

\section{The effect of M100907, SB242084 and WAY100635 on 25I-NBOMe-induced increase in DA levels in the rat frontal cortex}

The extracellular levels of DA were not changed by administration of the 5- $\mathrm{HT}_{2 \mathrm{~A}}, 5-\mathrm{HT}_{2 \mathrm{C}}$ and 5- $\mathrm{HT}_{1 \mathrm{~A}}$ receptor antagonists M100907, SB242084 and WAY100635, respectively, at a concentration of $100 \mathrm{nM}$ through a dialysis probe (Fig. 2a, $c, e)$. The dose of 1 and $3 \mathrm{mg} / \mathrm{kg}$ of 25I-NBOMe significantly $(p<0.01)$ increased extracellular levels of DA in the rat frontal cortex (Fig. 2a, c, e, respectively). M100907, SB242084 and WAY100635 suppressed 25I-NBOMe-induced increase in the extracellular DA levels, but the effect of M100907 was weaker than that of SB242084 and WAY100635 (Fig. 2a, c, e). Two-way repeated measures ANOVA showed a significant effect of 25I-NBOMe and M100907 $\left(F_{3,18}=314\right.$,

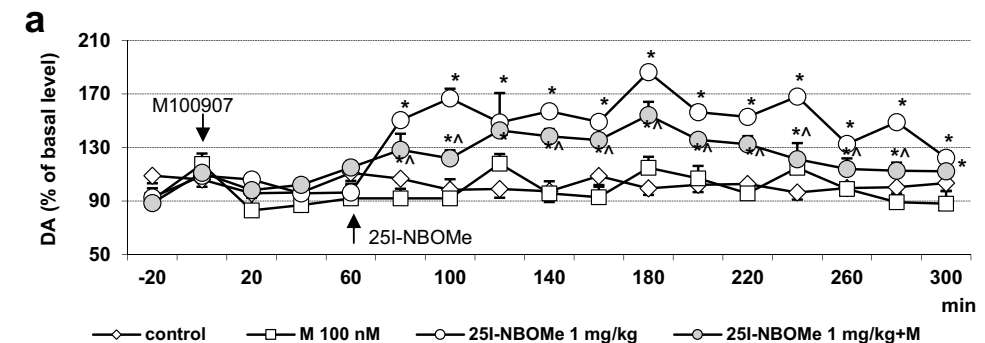

b

C
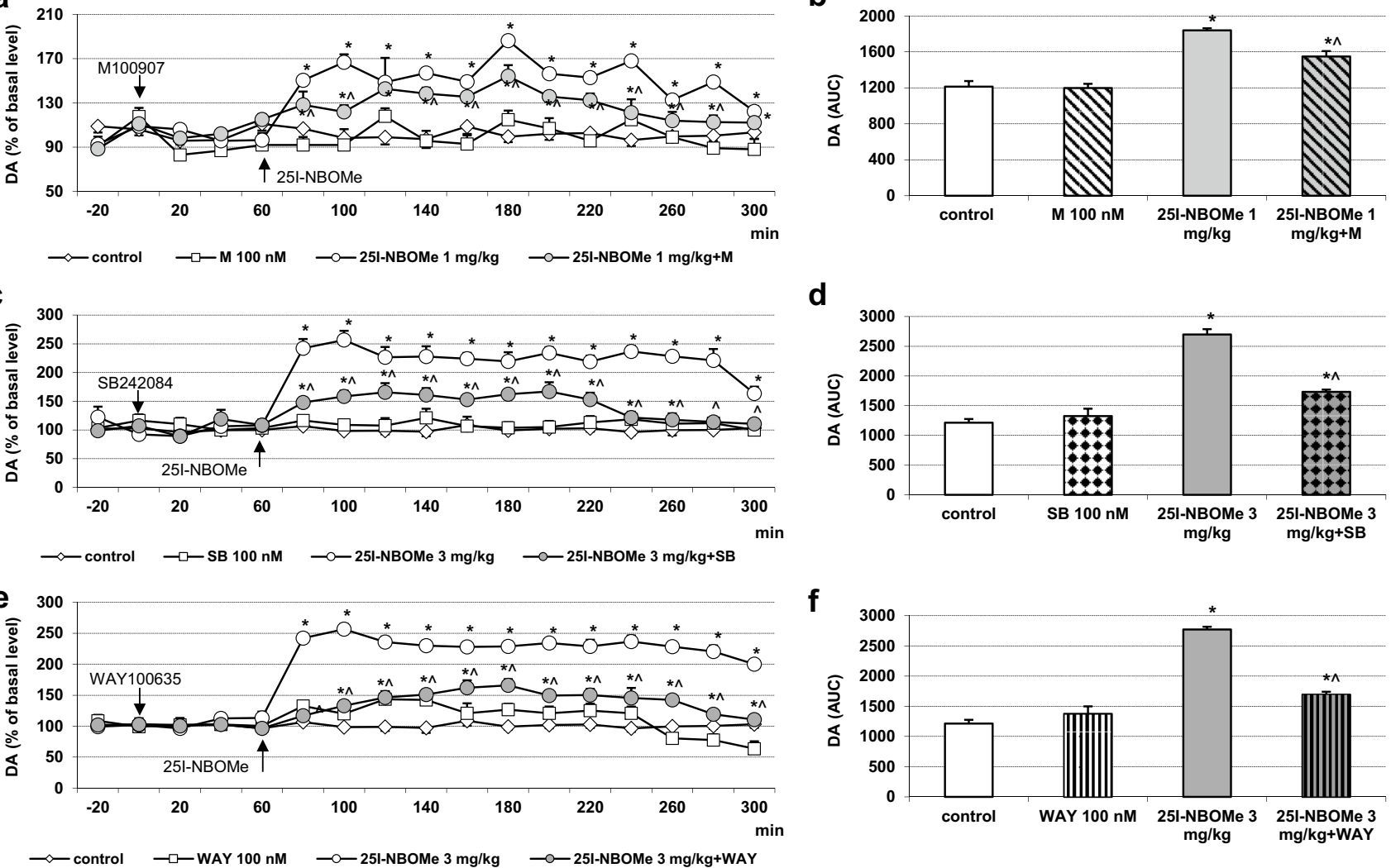

d

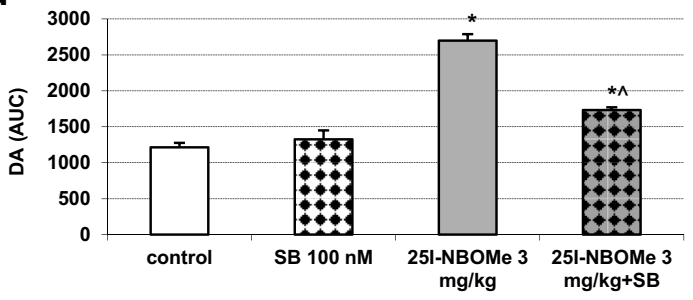

f

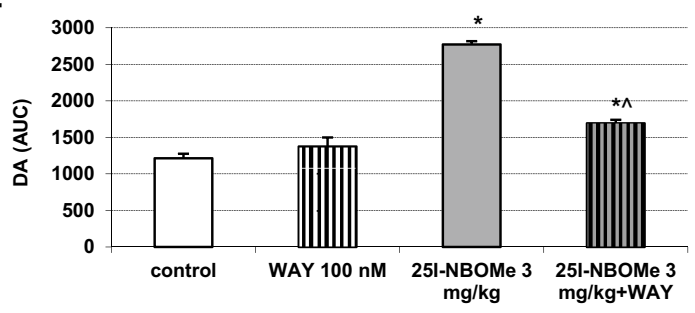

Fig. 2 The time-course (a, c, e) and total (b, d, f) effect of 25I-NBOMe and M100907, SB242084 and WAY100635, respectively on extracellular levels of dopamine (DA) in the rat frontal cortex. The total effect was calculated as an area under the concentration-time curve (AUC) and expressed as the percent of control. Values are the mean \pm standard error of the mean (SEM), $n=5-6$ per experimental group. The administration of drugs is indicated with arrows. ${ }^{*} p<0.01$ vs. control group; ${ }^{\wedge} p<0.01$ 25I-NBOMe vs. 25I-NBOMe + M100907, 25I-NBOMe + SB242084 or 25I-NBOMe + WAY100635 groups (two-way repeated measures ANOVA or two-way ANOVA where appropriate and Tukey's post hoc test) 
$p<0.0001)$, sampling period $\left(F_{11,198}=7.7, p<0.0001\right)$, and time $\times$ treatment interaction $\left(F_{33,198}=3.4, p<0.0001\right)$. The effect of treatment with 25I-NBOMe and SB242084 was also significant $\left(F_{3,18}=647, p<0.0001\right)$, there was an effect of sampling period $\left(F_{11,198}=10.4, p<0.0001\right)$ and time $\times$ treatment interaction $\left(F_{33,198}=5.7, p<0.0001\right)$. There was also an effect of treatment with 25I-NBOMe and WAY100635 $\left(F_{3,18}=586, p<0.0001\right)$, sampling period $\left(F_{11,198}=8.1, p<0.0001\right)$, and time $\times$ treatment interaction $\left(F_{33,198}=5.6, p<0.0001\right)$. The total effects expressed as AUC shown in Fig. 2b, d, f reflect the responses to 25I-NBOMe and 25I-NBOMe plus the 5- $\mathrm{HT}_{2 \mathrm{~A} / 2 \mathrm{C} / 1 \mathrm{~A}}$ receptor antagonists with respect to cortical DA release presented as time-course curves. Data set of the total effects was subjected to two-way ANOVA. The group factor was significant for 25I-NBOMe in each case: $F_{1,18}=753, p<0.0001$ (Fig. 2b); $F_{1,18}=1231, p<0.0001$ (Fig. 2 d) and $F_{1,18}=1358$, $p<0.0001$ (Fig. 2f). The group factor was also significant for M100907, SB242084: $F_{1,18}=66, p<0.0001 ; F_{1,18}=288$, $p<0.0001$ and WAY100635 $F_{1,18}=378, p<0.0001$ (Fig. 2b, $\mathrm{d}$ and $\mathrm{f}$, respectively). The group factor was significant for 25I-NBOMe + M100907 and 25I-NBOMe + SB242084: $F_{1,18}=74, p<0.0001 ; F_{1,18}=299, p<0.0001$, respectively and for 25I-NBOMe + WAY100635: $F_{1,18}=390$, $p<0.0001$ (Fig. 2b, d and f, respectively). Post hoc Tukey's test showed significant difference between control and 25I-NBOMe ( 1 and $3 \mathrm{mg} / \mathrm{kg}$ ) and 25I-NBOMe + M100907, 25I-NBOMe + SB242084 and 25I-NBOMe + WAY100635 groups $(p<0.01)$, and between 25I-NBOMe + M100907 and 25I-NBOMe + SB242084 and 25I-NBOMe + WAY100635 in comparison with 25I-NBOMe alone $(p<0.01)$ (Fig. 2b, $\mathrm{d}$ and $\mathrm{f}$.

\section{The effect of M100907, SB242084 and WAY100635 on 25I-NBOMe-induced increase in 5-HT levels in the rat frontal cortex}

The extracellular levels of 5-HT were not changed by administration of the 5- $\mathrm{HT}_{2 \mathrm{~A}}, 5-\mathrm{HT}_{2 \mathrm{C}}$ and 5- $\mathrm{HT}_{1 \mathrm{~A}}$ receptor antagonists M100907, SB242084 and WAY100635, respectively, at the concentration of $100 \mathrm{nM}$ through a dialysis probe (Fig. 3a, c, e). Both doses of 1 and $3 \mathrm{mg} /$ $\mathrm{kg}$ of $25 \mathrm{I}-\mathrm{NBOMe}$ significantly $(p<0.01)$ increased extracellular levels of 5-HT in the rat frontal cortex (Fig. 3a, c, e, respectively). SB242084 reduced the 25I-NBOMeinduced increase in extracellular 5-HT level nearly to the control values (Fig. 3c), while the effect of M100907 and WAY100635 was weaker but significant (Fig. 3a, e). Two-way repeated measures ANOVA showed a significant effect of treatment with 25I-NBOMe and M100907 on 5-HT release $\left(F_{3,18}=359, p<0.0001\right)$, sampling period $\left(F_{11,198}=46, p<0.0001\right)$, and time $\times$ treatment interaction $\left(F_{33,198}=15.8, p<0.0001\right)$. There was also an effect of treatment with 25I-NBOMe and SB242084 $\left(F_{3,18}=544\right.$, $p<0.0001)$, sampling period $\left(F_{11,198}=15.0, p<0.0001\right)$, and time $\times$ treatment interaction $\left(F_{33,198}=12.1\right.$, $p<0.0001)$. The effect of treatment with 25I-NBOMe and WAY 100635 was significant $\left(F_{3,18}=359, p<0.0001\right)$, as were sampling period $\left(F_{11,198}=46, p<0.0001\right)$ and the time $\times$ treatment interaction $\left(F_{33,198}=15.8, p<0.0001\right)$. Data set of the total effects was subjected to two-way ANOVA. The group factor was significant for 25I-NBOMe in each case: $F_{1,18}=986, p<0.0001$ (Fig. $3 b$ ) $; F_{1,18}=671$, $p<0.0001$ (Fig. 3d) and $F_{1,18}=986, p<0.0001$ (Fig. 3f). The group factor was also significant for M100907, SB242084: $F_{1,18}=23, p<0.0001 ; F_{1,18}=421, p<0.0001$ and WAY100635 $F_{1,18}=23, p<0.0001$ (Fig. 3b, d and $\mathrm{f}$, respectively). The group factor was significant for 25I-NBOMe + M100907 and 25I-NBOMe + SB242084: $F_{1,18}=28, p<0.0001 ; F_{1,18}=431, p<0.0001$, respectively, and for 25I-NBOMe + WAY100635: $F_{1,18}=28$, $p<0.0001$ (Fig. 3b, d and f, respectively). Post hoc Tukey's test showed significant difference between control and 25I-NBOMe ( 1 and $3 \mathrm{mg} / \mathrm{kg}$ ) and 25I-NBOMe + M100907, 25I-NBOMe + SB242084 and 25I-NBOMe + WAY100635 groups $(p<0.01)$ and between 25I-NBOMe + M100907 and 25I-NBOMe + SB242084 and 25I-NBOMe + WAY 100635 in comparison to 25I-NBOMe alone $(p<0.01)$ (Fig. 2b, d and f).

\section{Basal levels of glutamate, DA and 5-HT in the rat frontal cortex}

In the rat, basal levels of glutamate expressed in $\mathrm{ng} / 10 \mu \mathrm{l}$ of dialysate in the frontal cortex averaged $2.88 \pm 0.18(n=48)$. Basal DA levels expressed in $\mathrm{pg} / 10 \mu \mathrm{l}$ of dialysate were $1.56 \pm 0.09(n=48) .5$-HT basal levels expressed in $\mathrm{pg} / 10 \mu \mathrm{l}$ of dialysate were $0.73 \pm 0.05(n=48)$. No differences in basal levels between experimental groups were observed. The values were not corrected for the in vitro probe recovery.

\section{The effect of M100907, SB242084 and WAY100635 on 25I-NBOMe-induced wet dog shakes in rats}

Rats treated with saline, M100907, SB242084 or WAY100635 (100 nM) showed a minimal behavior rated as WDS (Fig. 4). Injection of 25I-NBOMe-induced WDS, and the response after the dose of $1 \mathrm{mg} / \mathrm{kg}\left(F_{1,23}=6.47, p<0.02\right)$ was more potent than after $3 \mathrm{mg} / \mathrm{kg}\left(F_{1,25}=6.57, p<0.02\right)$ (Fig. 4). M100907 and SB242084 but not WAY100635 significantly suppressed 25I-NBOMe-induced WDS response (Fig. 4). Two-way ANOVA showed a significant effect of $\operatorname{M100907}\left(F_{1,23}=4.53, p<0.05\right), \mathrm{SB} 242084\left(F_{1,25}=6.57\right.$, $p<0.02)$ but not WAY100635 $\left(F_{1,25}=0.09, p<0.76\right)$. 

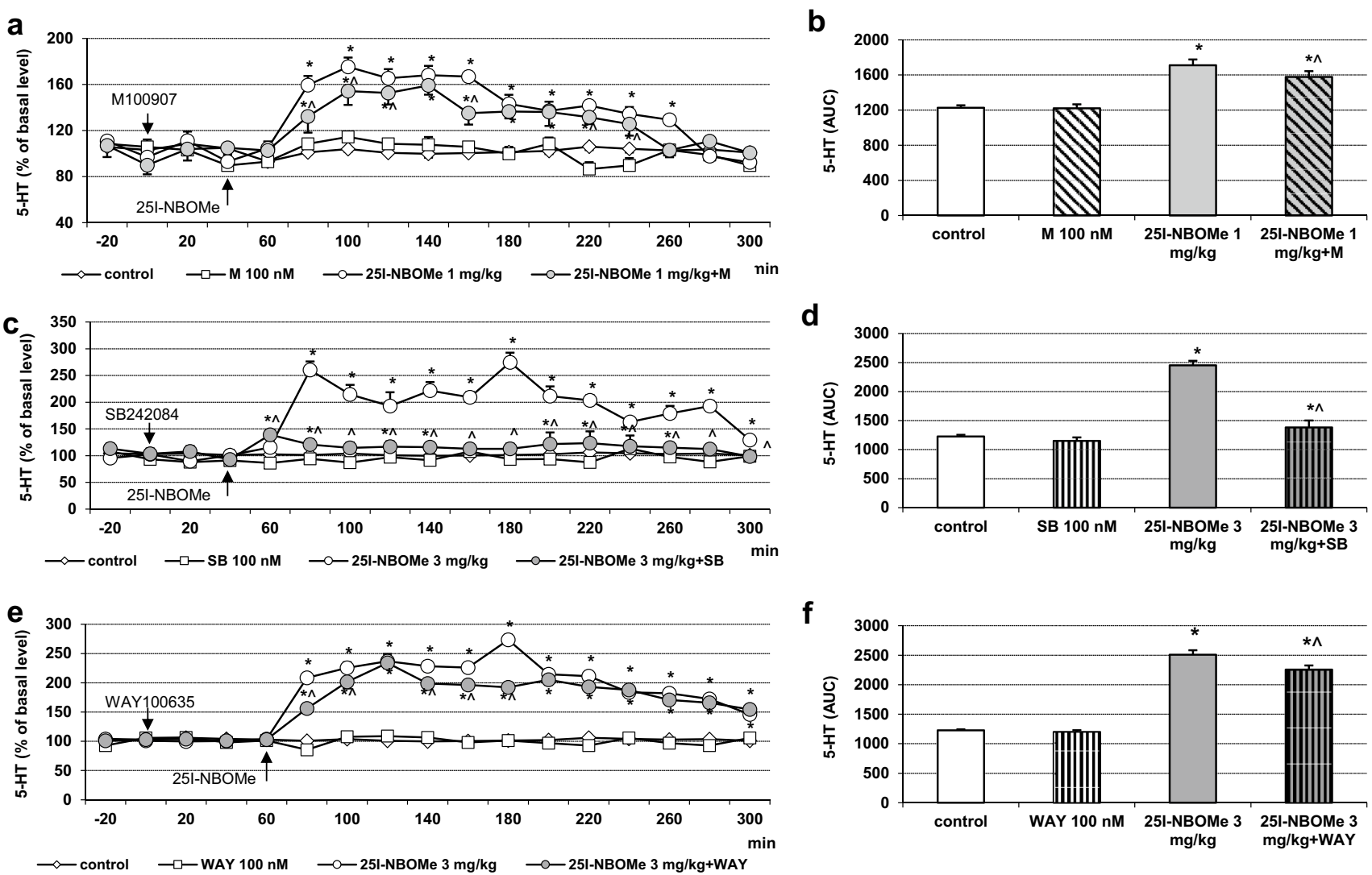

Fig. 3 The time-course (a, c, e) and total (b, d, f) effect of 25I-NBOMe and M100907, SB242084 and WAY100635, respectively on extracellular levels of serotonin $(5-\mathrm{HT})$ in the rat frontal cortex. The total effect was calculated as an area under the concentration-time curve (AUC) and expressed as the percent of control. Values are the mean \pm standard error of the mean (SEM), $n=5-6$ per experimental group. The administration of drugs is indicated with arrows. $* p<0.01$ vs. control group; ${ }^{\wedge} p<0.01$ 25I-NBOMe vs. 25I-NBOMe + M100907, 25I-NBOMe + SB242084 or 25I-NBOMe + WAY100635 groups (two-way repeated measures ANOVA or two-way ANOVA where appropriate and Tukey's post hoc test)

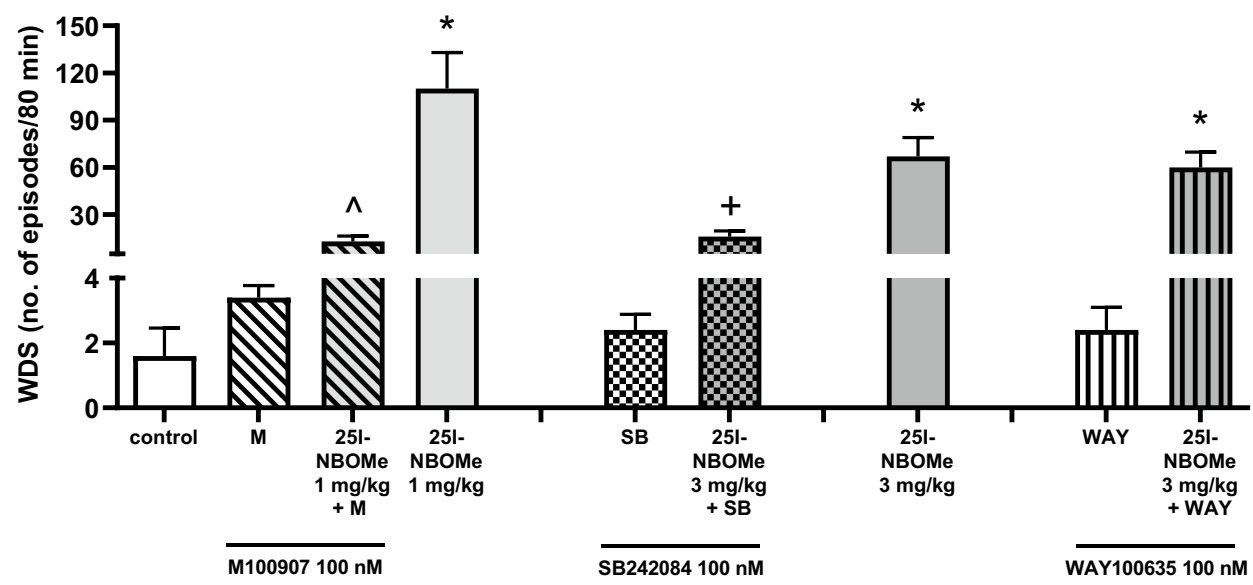

Fig. 4 The effect of 25I-NBOMe and M100907, SB242084 and WAY100635, respectively on wet dog shakes (WDS). The number of WDS episodes was counted for 240 min starting immediately after the drug administration. Values are the mean \pm standard error of the mean (SEM), $n=5-14$ per experimental group. $* p<0.02$ vs. control group; ${ }^{\wedge} p<0.05$ 25I-NBOMe vs. 25I-NBOMe + M100907; $+p<0.02$ 25I-NBOMe vs. 25I-NBOMe $+\mathrm{SB} 242084$ group (two-way ANOVA and Tukey's post hoc test) 


\section{Discussion}

Acute 25I-NBOMe treatment enhanced extracellular levels of glutamate, DA and 5-HT in the rat frontal cortex. Local intra-cortical administration of the selective serotonin 5- $\mathrm{HT}_{2 \mathrm{~A}}, 5-\mathrm{HT}_{2 \mathrm{C}}$ and $5-\mathrm{HT}_{1 \mathrm{~A}}$ receptor antagonists M100907, SB242084 and WAY100635, respectively, at a concentration of $100 \mathrm{nM}$ inhibited the increase in the DA and 5-HT levels, while the increase in the glutamate level was only reduced by M100907 and SB242084, but not by WAY100635. Furthermore, 25I-NBOMe-induced hallucinogenic activity in rats was attenuated by the $5-\mathrm{HT}_{2 \mathrm{~A}}$ and 5- $\mathrm{HT}_{2 \mathrm{C}}$ antagonists M100907 and SB242084 but not by WAY 100635 .

As shown in several studies, the $5-\mathrm{HT}_{2 \mathrm{~A}}$ receptor in the frontal cortex is critically involved in hallucinogenic activity in rodents $[6,14,16,19,25]$. Furthermore, the glutamatergic system also appears to play a role in the effects of serotonergic hallucinogens since in vivo studies have shown that the stimulation of cortical $5-\mathrm{HT}_{2 \mathrm{~A}}$ receptors caused the release of glutamate [6, 7, 9]. 25I-NBOMe is a potent $5-\mathrm{HT}_{2 \mathrm{~A}}$ receptor agonist with sub-nanomolar affinity and it is slightly weaker at $5-\mathrm{HT}_{2 \mathrm{C}}$ receptors, while showing low $\mu \mathrm{M}$ affinity at $5-\mathrm{HT}_{1 \mathrm{~A}}$ receptors [1]. Our earlier study showed an inverted "U"-shaped dose-response effect of 25I-NBOMe in increasing extracellular DA and 5-HT levels and a "U"-shaped dose-response effect in glutamate release and hallucinogenic activity in rats [6]. Notably, the 25I-NBOMe dose of $1 \mathrm{mg} / \mathrm{kg}$ was most potent in increasing glutamate release and hallucinogenic activity, while the dose of $3 \mathrm{mg} / \mathrm{kg}$ was weakest [6]. We hypothesized that 25I-NBOMe at a dose of $1 \mathrm{mg} / \mathrm{kg}$ exerted its effect on WDS and glutamate release via the $5-\mathrm{HT}_{2 \mathrm{~A}}$ receptors, while at higher doses, the response was negatively modulated via the $5-\mathrm{HT}_{2 \mathrm{C}}$ and $5-\mathrm{HT}_{1 \mathrm{~A}}$ receptors. Local perfusion of $100 \mathrm{nM}$ M100907, a selective 5- $\mathrm{HT}_{2 \mathrm{~A}}$ receptor antagonist significantly reduced WDS response and increased cortical glutamate release. Our data are consistent with the earlier studies indicating the reduction of the behavioral effect of 25I-NBOMe or DOI by M100907 in mice and rats $[13,16,18]$. In the aforementioned studies, the 5- $\mathrm{HT}_{2 \mathrm{~A}}$ antagonist was administered peripherally, while in our experiments, M100907 was infused through a microdialysis probe directly into the frontal cortex. Assuming 8-10\% in vitro probe recovery, the concentration of the antagonist in the close proximity of the probe was in low $\mathrm{nM}$ range, ensuring selective response. The effect of 25I-NBOMe at a higher dose of $3 \mathrm{mg} / \mathrm{kg}$ on the glutamate release and WDS was significantly decreased by local infusion of 100 nM SB242084, a 5- $\mathrm{HT}_{2 \mathrm{C}}$ selective receptor antagonist. As mentioned in Introduction, the $5-\mathrm{HT}_{2 \mathrm{~A}}$ receptors are mainly expressed on the apical dendrites of pyramidal cells in layer $\mathrm{V}$ of the cerebral cortex [3] with a minor localization to GABAergic interneurons $[4,5]$. In contrast, the $5-\mathrm{HT}_{2 \mathrm{C}}$ receptors are mainly expressed on GABAergic cells in the deep layers of the prefrontal cortex and may exert an inhibitory tone on pyramidal neurons by GABA release [10, 11]. Thus, the activation of $5-\mathrm{HT}_{2 \mathrm{C}}$ receptors located on GABAergic interneurons by a higher dose of 25I-NBOMe could be the cause of a weaker effect of the compound on glutamate release and WDS response. Consequently, it may be expected that the $5-\mathrm{HT}_{2 \mathrm{C}}$ receptor blockade by SB242084 should disinhibit pyramidal neurons by liberating them from inhibitory control of GABA, resulting in the increased release of glutamate and increased WDS response in comparison to $25 \mathrm{I}-\mathrm{NBOMe}$ alone group. Unexpectedly, local infusion of SB242084 in the frontal cortex decreased 25I-NBOMe-induced glutamate release and WDS to the control values. This effect seems to be in contrast to the study by Vickers et al. [25] which demonstrated that a $5-\mathrm{HT}_{2 \mathrm{C}}$ receptor agonist inhibited $5-\mathrm{HT}_{2 \mathrm{~A}}$ receptor-mediated head twitches in rats while the number of head-twitches induced by $5-\mathrm{HT}_{2 \mathrm{~A}}$ receptor agonists was greater in the presence of SB242084 [25]. Similarly, $5-\mathrm{HT}_{2 \mathrm{C}}$ antagonists dose-dependently increased headtwitch behavior elicited by the $5-\mathrm{HT}_{2 \mathrm{~A}}$ agonist, DOI in mice [16]. On the other hand, the DOI-elicited head-twitch response was reduced in $5-\mathrm{HT}_{2 \mathrm{C}}$ receptor-knockout mice [21] indicating that $5-\mathrm{HT}_{2 \mathrm{C}}$ receptors are required for this behavior. Our contrasting data may be explained, to some extent, by a different way of drug administration. In the cited papers, 5-HT receptor antagonists were administered systematically, while in the present work, the drugs were infused locally into the frontal cortex. Thus, only a limited population of receptors could have been affected during infusion into the frontal cortex whereas receptors in other locations as fully functional might allow for adjustment of the response. Furthermore, co-expression of the $5-\mathrm{HT}_{2 \mathrm{~A}}$ and $5-\mathrm{HT}_{2 \mathrm{C}}$ serotonin receptors on cells in the frontal cortex and their functional interaction needs to be taken into account for explanation of our data. The work of Nocjar et al. [10] demonstrated that a majority (73\%) of cells that co-express the $5-\mathrm{HT}_{2 \mathrm{C}}$ and $5-\mathrm{HT}_{2 \mathrm{~A}}$ receptors are GABA cells, and only some pyramidal cells (remaining $27 \%$ ) were found to express the $5-\mathrm{HT}_{2 \mathrm{C}}$ ad $5-\mathrm{HT}_{2 \mathrm{~A}}$ receptors in layers $\mathrm{V}-\mathrm{VI}$ of the medial prefrontal cortex. However, only $28-53 \%$ of $5-\mathrm{HT}_{2 \mathrm{~A}}$ receptor-expressing pyramidal cells co-expressed 5- $\mathrm{HT}_{2 \mathrm{C}}$ receptor mRNA [26]. Hence, $5-\mathrm{HT}_{2 \mathrm{C}}$ and $5-\mathrm{HT}_{2 \mathrm{~A}}$ receptor co-expression may affect cortical cell function in a different way. Taking into account differential location of receptor subtypes, $5-\mathrm{HT}_{2 \mathrm{~A}}$ receptor agonists enhance local pyramidal cell excitation [27], while local treatment with $5-\mathrm{HT}_{2 \mathrm{C}}$ agonists triggers GABA cell excitation, but in turn, the released GABA may 
inhibit pyramidal cell function [28]. It has been suggested that GABAergic cells expressing both receptors are most likely regulated by their functional balance as evidenced at the level of intraneuronal signaling pathways. 5- $\mathrm{HT}_{2 \mathrm{~A}}$ and $5-\mathrm{HT}_{2 \mathrm{C}}$ receptors activate many of the same second messenger signaling systems [29, 30], but they may also recruit different intracellular signaling routes [31]. Data show that GABA cell stimulation induced by intra-cortical infusion of the $5-\mathrm{HT}_{2 \mathrm{~A} / 2 \mathrm{C}}$ receptor agonist DOI was partially blocked by a $5-\mathrm{HT}_{2 \mathrm{C}}$ antagonist, while being completely blocked by dual 5- $\mathrm{HT}_{2 \mathrm{~A} / 2 \mathrm{C}}$ antagonism [32]. Since 5- $\mathrm{HT}_{2 \mathrm{~A}}$ and $5-\mathrm{HT}_{2 \mathrm{C}}$ receptors are co-expressed on both pyramidal and GABAergic cells in the frontal cortex, thus, apart from 5- $\mathrm{HT}_{2 \mathrm{~A}}$ receptors, $5-\mathrm{HT}_{2 \mathrm{C}}$ receptors with pyramidal location may take part in the 25I-NBOMeinduced increase in extracellular glutamate level and this effect may be suppressed by local infusion of the $5-\mathrm{HT}_{2 \mathrm{C}}$ receptor antagonist SB242084. Another possibility of pyramidal cell regulation could involve the blockade of $5-\mathrm{HT}_{2 \mathrm{C}}$ receptors located on GABAergic cells. In the presence of SB242084, the activation of 5- $\mathrm{HT}_{2 \mathrm{~A}}$ receptors on GABAergic interneurons may indirectly inhibit glutamate release from pyramidal cells by increasing GABA release.

Other serotonergic receptor subtypes are also coexpressed within the frontal cortex. $5-\mathrm{HT}_{1 \mathrm{~A}}$ and $5-\mathrm{HT}_{2 \mathrm{~A}}$ receptors are co-localized on the majority of pyramidal cells $[17,33]$ and there is evidence of their opposing cross-talk [17]. Thus, excitation of pyramidal neurons by $5-\mathrm{HT}_{2 \mathrm{~A}}$ receptor agonists might be reversed by inhibitory $5-\mathrm{HT}_{1 \mathrm{~A}}$ receptor agonists or potentiated by antagonists of this receptor. In light of this cross-talk, 5- $\mathrm{HT}_{1 \mathrm{~A}}$ antagonists can augment the HTR induced by hallucinogen administration. However, infusion of the $5-\mathrm{HT}_{1 \mathrm{~A}}$ receptor antagonist WAY100635 did not change the 25I-NBOMe effect on the glutamate release and WDS response, as shown in our study. The help in answering this question may come from a recent report by Yuen et al. [34], who indicated that local 5- $\mathrm{HT}_{2 \mathrm{~A} / 2 \mathrm{C}}$ receptor co-activation opposed the function of inhibitory 5-HT ${ }_{1 \mathrm{~A}}$ receptor. Possibly, co-administration of 25I-NBOMe as an agonist of $5-\mathrm{HT}_{2 \mathrm{~A} / 2 \mathrm{C}}$ receptors with WAY 100635 could alter the sensitivity of 5- $\mathrm{HT}_{1 \mathrm{~A}}$ receptor and dampen its signaling pathways. Another issue which has to be considered to explain the observed effect is the receptor interaction profile of 25I-NBOMe. The in vitro affinity of 25I-NBOMe for $5-\mathrm{HT}_{1 \mathrm{~A}}$ receptors is ca. 2000 fold lower than for $5-\mathrm{HT}_{2 \mathrm{~A}}$ receptors [1]. Therefore, likely much higher concentration of $25 \mathrm{I}-\mathrm{NBOMe}$ in the vicinity of 5-HT ${ }_{1 \mathrm{~A}}$ receptors is necessary to counterbalance the agonist effect of this hallucinogen via $5-\mathrm{HT}_{1 \mathrm{~A}}$ receptors on the WDS response and glutamate release in the frontal cortex.

Frontal cortex neurons play an important role in the direct and indirect processing of information along the basal ganglia circuits via 5-HT receptors. Cortical output neurons innervate serotonergic dorsal and medial raphe cells and midbrain dopaminergic neurotransmission. In turn, the frontal cortex receives serotonergic and dopaminergic input from the midbrain raphe and ventral tegmental area (VTA) neurons [35, 36]. We observed lower extracellular DA and 5-HT levels in groups treated with 25I-NBOMe and M100907 or SB242084. It seems likely that weakened stimulation from the descending glutamatergic pathways onto raphe and VTA cells after coadministration of these drugs results in the reduced effect of the drugs on midbrain raphe and VTA neurons leading to lower DA and 5-HT release from the neuronal terminals in the frontal cortex. Surprisingly, in spite of no effect of WAY 100635 on the 25I-NBOMe-induced glutamate release, lower extracellular DA and 5-HT levels were found in groups receiving this drug combination. It has been evidenced that the 5- $\mathrm{HT}_{1 \mathrm{~A}}$ receptors are located postsynaptically on pyramidal and GABAergic neurons of the cortex [33, 37]. However, $5-\mathrm{HT}_{1 \mathrm{~A}}$ agonists were reported to act preferentially on GABAergic neurons [38]. Therefore, under conditions of 25I-NBOMe and WAY 100635 co-administration, the blockade of $5-\mathrm{HT}_{1 \mathrm{~A}}$ receptors by WAY 100635 may disinhibit GABA cells by releasing them from $5-\mathrm{HT}_{1 \mathrm{~A}}$ receptor control with subsequent decrease in output from DA and 5-HT terminals.

To conclude, the results of our study indicate that predominantly $5-\mathrm{HT}_{2 \mathrm{~A}}$ receptor is crucial in the regulation of glutamate, DA and 5-HT release from pyramidal cells and in hallucinogenic activity of 25I-NBOMe, however, $5-\mathrm{HT}_{2 \mathrm{C}}$ subtype seems to be also required in the neurochemical and behavioral effects of this hallucinogen. The lack of noticeable influence of $5-\mathrm{HT}_{1 \mathrm{~A}}$ receptor blockade on the WDS response and glutamate release in the frontal cortex seems to result from a low binding affinity of 25I-NBOMe at these sites or damping of $5-\mathrm{HT}_{1 \mathrm{~A}}$ receptor signaling by $5-\mathrm{HT}_{2 \mathrm{~A} / 2 \mathrm{C}}$ receptors. The suppressive effect of WAY 100635 on DA and 5-HT release in the frontal cortex may result from disinhibition of GABA interneurons by $5-\mathrm{HT}_{1 \mathrm{~A}}$ receptor blockade.

Author contributions KG designed the study and wrote the protocol. MH, MKS, MS, AW and AGM performed the experiments. MH and MKS prepared the section of introduction and experimental procedure, $\mathrm{MH}$ and KG described the obtained results and wrote the discussion. $\mathrm{KG}$ carried out the statistical analysis and was involved in making the graphical representation of the data. All authors contributed to and have approved the final manuscript.

Funding This study was supported by the National Science Centre, Krakow, Poland (grant no. 2016/21/B/NZ7/01131). MH acknowledges the support of InterDokMed (project no. POWR.03.02.00-00-I013/16). A part of this study was funded also by the Maj Institute of Pharmacology of the Polish Academy of Sciences statutory fund. The funding sources had no role in the design of the study, collection and analysis of data and decision to publish. 


\section{Compliance with ethical standards}

Conflict of interest All authors declare that they have no conflicts of interest.

Open Access This article is licensed under a Creative Commons Attribution 4.0 International License, which permits use, sharing, adaptation, distribution and reproduction in any medium or format, as long as you give appropriate credit to the original author(s) and the source, provide a link to the Creative Commons licence, and indicate if changes were made. The images or other third party material in this article are included in the article's Creative Commons licence, unless indicated otherwise in a credit line to the material. If material is not included in the article's Creative Commons licence and your intended use is not permitted by statutory regulation or exceeds the permitted use, you will need to obtain permission directly from the copyright holder. To view a copy of this licence, visit http://creativecommons.org/licenses/by/4.0/.

\section{References}

1. Rickli A, Luethi D, Reinisch J, Buchy D, Hoener MC, Liechti ME. Receptor interaction profiles of novel N-2-methoxybenzyl (NBOMe) derivatives of 2,5-dimethoxy-substituted phenethylamines (2C drugs). Neuropharmacology. 2015;99:546-53.

2. Nichols DE. Hallucinogens. Pharmacol Ther. 2004;101:131-81.

3. Weber ET, Andrade R. Htr2a gene and 5-HT2A receptor expression in the cerebral cortex studied using genetically modified mice. Front Neurosci. 2010;4:1-12.

4. Miner LAH, Backstrom JR, Sanders-Bush E, Sesack SR. Ultrastructural localization of serotonin2A receptors in the middle layers of the rat prelimbic prefrontal cortex. Neuroscience. 2003;116:107-17.

5. Willins DL, Deutch AY, Roth BL. Serotonin 5-HT(2A) receptors are expressed on pyramidal cells and interneurons in the rat cortex. Synapse. 1997;27:79-82.

6. Herian M, Wojtas A, Kamińska K, Świt P, Wach A, Gołembiowska K. Hallucinogen-like action of the novel designer drug 25I-NBOMe and its effect on cortical neurotransmitters in rats. Neurotox Res. 2019;36:91-100.

7. Muschamp JW, Regina MJ, Hull EM, Winter JC, Rabin RA. Lysergic acid diethylamide and [-]-2,5-dimethoxy-4-methylamphetamine increase extracellular glutamate in rat prefrontal cortex. Brain Res. 2004;1023:134-40.

8. Noworyta-Sokołowska K, Kamińska K, Kreiner G, Rogóż Z, Gołembiowska K. Neurotoxic effects of 5-MeO-DIPT: a psychoactive tryptamine derivative in rats. Neurotox Res. 2016;30:606-19.

9. Scruggs JL, Schmidt D, Deutch AY. The hallucinogen 1-[2,5-dimethoxy-4-iodophenyl]-2-aminopropane (DOI) increases cortical extracellular glutamate levels in rats. Neurosci Lett. 2003;346:137-40.

10. Nocjar C, Alex KD, Sonneborn A, Abbas AI, Roth BL, Pehek EA. Serotonin-2c and -2a receptor co-expression on cells in the rat medial prefrontal cortex. Neuroscience. 2015;297:22-37.

11. Santana N, Artigas F. Expression of serotonin $2 \mathrm{C}$ receptors in pyramidal and GABAergic neurons of rat prefrontal cortex: a comparison with striatum. Cereb Cortex. 2017;27:3125-39.

12. Garcia-Garcia AL, Newman-Tancredi A, Leonardo ED. 5-HT1A receptors in mood and anxiety: Recent insights into autoreceptor versus heteroreceptor function. Psychopharmacology. 2014;231:623-36.
13. Halberstadt AL, Geyer MA. Characterization of the head-twitch response induced by hallucinogens in mice: detection of the behavior based on the dynamics of head movement. Psychopharmacology. 2013;227:727-39.

14. Klein LM, Cozzi NV, Daley PF, Brandt SD, Halberstadt AL. Receptor binding profiles and behavioral pharmacology of ringsubstituted N, N-diallyltryptamine analogs. Neuropharmacology. 2018;142:231-9.

15. Halberstadt AL, Van Der Heijden I, Ruderman MA, Risbrough VB, Gingrich JA, Geyer MA, et al. 5-HT 2A and 5-HT 2C receptors exert opposing effects on locomotor activity in mice. Neuropsychopharmacology. 2009;34:1958-67.

16. Fantegrossi WE, Simoneau J, Cohen MS, Zimmerman SM, Henson CM, Rice KC, et al. Interaction of 5-HT2A and 5-HT2C receptors in $\mathrm{R}(-)$-2,5-dimethoxy-4-iodoamphetamine-elicited head twitch behavior in mice. J Pharmacol Exp Ther. 2010;335:728-34.

17. Martín-Ruiz R, Puig MV, Celada P, Shapiro DA, Roth BL, Mengod $\mathrm{G}$, et al. Control of serotonergic function in medial prefrontal cortex by serotonin-2A receptors through a glutamate-dependent mechanism. J Neurosci. 2001;21:9856-66.

18. Elmore JS, Decker AM, Sulima A, Rice KC, Partilla JS, Blough BE, et al. Comparative neuropharmacology of $\mathrm{N}$-(2-methoxybenzyl)-2,5-dimethoxyphenethylamine (NBOMe) hallucinogens and their $2 \mathrm{C}$ counterparts in male rats. Neuropharmacology. 2018;142:240-50.

19. Halberstadt AL, Geyer MA. Effects of the hallucinogen 2,5-dimethoxy-4-iodophenethylamine (2C-I) and superpotent $\mathrm{N}$-benzyl derivatives on the head twitch response. Neuropharmacology. 2014;77:200-7.

20. Buchborn T, Lyons T, Knöpfel T. Tolerance and tachyphylaxis to head twitches induced by the $5-\mathrm{HT} 2 \mathrm{~A}$ agonist $25 \mathrm{CN}-\mathrm{NBOH}$ in mice. Front Pharmacol. 2018;9:17.

21. Canal CE, Da Silva UBO, Gresch PJ, Watt EE, Sanders-Bush $\mathrm{E}$, Airey DC. The serotonin $2 \mathrm{C}$ receptor potently modulates the head-twitch response in mice induced by a phenethylamine hallucinogen. Psychopharmacology. 2010;209:163-74.

22. Paxinos G, Watson C. The rat brain in stereotaxic coordinates. San Diego: Academic Press; 1998.

23. Rowley HL, Martin KF, Marsden CA. Determination of in vivo amino acid neurotransmitters by high-performance liquid chromatography with o-phthalaldehyde-sulphite derivatisation. J Neurosci Methods. 1995;57:93-9.

24. Nagayama H, Lu JQ. Circadian rhythm in the responsiveness of central 5-HT(2A) receptor to DOI in rats. Psychopharmacology. 1996;127:113-6.

25. Vickers SP, Easton N, Malcolm CS, Allen NH, Porter RH, Bickerdike MJ, et al. Modulation of 5-HT2A receptor-mediated headtwitch behaviour in the rat by $5-\mathrm{HT} 2 \mathrm{C}$ receptor agonists. Pharmacol Biochem Behav. 2001;69:643-52.

26. Carr DB, Cooper DC, Ulrich SL, Spruston N, Surmeier DJ. Serotonin receptor activation inhibits sodium current and dendritic excitability in prefrontal cortex via a protein kinase C-dependent mechanism. J Neurosci. 2002;22:6846-55.

27. Lambe EK, Aghajanian GK. Hallucinogen-induced UP states in the brain slice of rat prefrontal cortex: Role of glutamate spillover and NR2B-NMDA receptors. Neuropsychopharmacology. 2006;31:1682-9.

28. Maćkowiak M, Chocyk A, Fijał K, Czyrak A, Wȩdzony K. c-Fos proteins, induced by the serotonin receptor agonist DOI, are not expressed in 5-HT2A positive cortical neurons. Mol Brain Res. 1999;71:358-63.

29. Liu Y, Fanburg BL. Phospholipase D signaling in serotonininduced mitogenesis of pulmonary artery smooth muscle cells. Am J Physiol-Lung Cell Mol Physiol. 2008;295:L471-8.

30. McGrew L, Chang MSS, Sanders-Bush E. Phospholipase D activation by endogenous 5 -hydroxytryptamine $2 \mathrm{C}$ receptors is 
mediated by $\mathrm{G} \alpha 13$ and pertussis toxin-insensitive $\mathrm{G} \beta \gamma$ subunits. Mol Pharmacol. 2002;62:1339-43.

31. Berg KA, Maayani S, Goldfarb J, Scaramellini C, Leff P, Clarke WP. Effector pathway-dependent relative efficacy at serotonin type 2A and 2C receptors: evidence for agonist-directed trafficking of receptor stimulus. Mol Pharmacol. 1998;54:94-104.

32. Zhang QJ, Wang S, Liu J, Ali U, Gui ZH, Wu ZH, et al. Unilateral lesion of the nigrostriatal pathway decreases the response of interneurons in medial prefrontal cortex to $5-\mathrm{HT} 2 \mathrm{~A} / 2 \mathrm{C}$ receptor stimulation in the rat. Brain Res. 2010;1312:127-37.

33. Santana N, Bortolozzi A, Serrats J, Mengod G, Artigas F. Expression of serotonin $1 \mathrm{~A}$ and serotonin2A receptors in pyramidal and GABAergic neurons of the rat prefrontal cortex. Cereb Cortex. 2004;14:1100-9.

34. Yuen EY, Jiang Q, Chen P, Feng J, Yan Z. Activation of 5-HT2A/C receptors counteracts 5-HT1A regulation of $\mathrm{N}$-methyl-D-aspartate receptor channels in pyramidal neurons of prefrontal cortex. J Biol Chem. 2008;283:17194-204.

35. Di Matteo V, Di Giovanni G, Pierucci M, Esposito E, Farmacologiche R, Negri M, et al. Serotonin control of central dopaminergic function: focus on in vivo microdialysis studies. Prog Brain Res. 2008;172:7-44.

36. Soiza-Reilly M, Commons KG. Glutamatergic drive of the dorsal raphe nucleus. J Chem Neuroanat. 2011;41(4):247-55.

37. Pazos A, Palacios JM. Quantitative autoradiographic mapping of serotonin receptors in the rat brain. I. Serotonin-1 receptors. Brain Res. 1985;346:205-30.

38. Lladó-Pelfort L, Santana N, Ghisi V, Artigas F, Celada P. 5-HT 1A Receptor agonists enhance pyramidal cell firing in prefrontal cortex through a preferential action on GABA interneurons. Cereb Cortex. 2012;22:1487-97.

Publisher's Note Springer Nature remains neutral with regard to jurisdictional claims in published maps and institutional affiliations. 